\title{
Childhood Infratentorial Neoplasm
}

National Cancer Institute

\section{Source}

National Cancer Institute. Childhood Infratentorial Neoplasm. NCI Thesaurus. Code C5802.

A neoplasm that affects the infratentorial region of the brain and occurs during childhood. 